\title{
ВИНИКНЕННЯ ТА РОЗВИТОК ІДЕЇ СТВОРЕННЯ МІЖНАРОДНОГО КРИМІНАЛЬНОГО СУДУ ЯК ПОСТІЙНОГО ОРГАНУ МІЖНАРОДНОЇ КРИМІНАЛЬНОЇ ЮСТИЦІї
}

\begin{abstract}
Анотація. Міжнародний кримінальний суд являе собою унікальний орган міжнародної кримінальної юрисдикції. На сьогодні це перший правовий інститут, що діе на постійній основі. Серед особлівіостей, що вірізняють Міжнародний кримінальний суд серед інших міжнародних та змішаних судових установ, можна виділити також предметну юрисдикцію. Так, до компетенції Міжнародного кримінального суду віднесено переслідування осіб, винних у геноциді, воєнних злочинах, злочинах проти людяності. Заснований на основі Римського статуту, який було прийнято у 1998 році, Міжнародний кримінальний суд почав працювати у 2002 році. Незважаючи на короткий строк діяльності, вже показав свою ефективність у кількох справах. В основу діяльності Міжнародного кримінального суду покладено принципи кримінального права, притаманні більшості національних правових систем. Стаття присвячена виникненню та розвитку ідеї створення міжнародного кримінального суду як органу міжнародної кримінальної юстиції, що діє на постійній основі. Автором висвітлено основні історичні передумови та політико-правові засади створення Міжнародного кримінального суду. Розглянуто та проаналізовано основні нормативно-правові акти, що встановлювали відповідальність за скоєння тяжких та особливо тяжких злочинів масштабного характеру, а також документів, якими було закріплена процедура кримінального переслідування за такі діяння. Разом з тим, автор вказуе на недосконалість тимчасових міжнародних та змішаних судових установ , що існували до появи ідеї створення постійного органу кримінальної юстиції міжнародного рівня. Попри багатовікову історію воєнних злочинів та злочинів проти людства, а також існування інститутів покарання за ці злочини, вперше ідея створення міжнародного судового органу, до юрисдикції якого б входив розгляд справ про злочини проти людства та військові злочини, з'явилась у післявоенні роки Першої світової війни. Також автор наводить та аналізуе доктринальні підходи щодо моменту виникнення ідеї створення Міжнародного кримінального суду, адже вченими першої половини XX ст. було висунуто різні ідеї та концепщії створення постійно діючого органу міжнародної кримінальної юстиції, до компетентності якого було б віднесено розгляд злочинів геноциду та інших нелюдських дій.
\end{abstract}

Ключові слова: Міжнародний кримінальний суд, міжнародна кримінальна юрисдикція, міжнародний злочин, воєнні злочини, злочини проти людства, міжнародний договір.

Nevinchanyi Mykola

V.I. Vernadsky Taurida National University

\section{THE EMERGENCE AND DEVELOPMENT OF THE IDEA OF CREATING AN INTERNATIONAL CRIMINAL COURT AS A CONSTANT ORGANIZATION OF INTERNATIONAL CRIMINAL JUSTICE}

Summary. The International Criminal Court is a unique organization of international criminal jurisdiction. Today it is the first legal institution to operate on a permanent basis. Among the features that distinguish the International Criminal Court from other international and mixed judicial institutions, we can also highlight the subject jurisdiction. Thus, the jurisdiction of the International Criminal Court includes the prosecution of persons guilty of genocide, war crimes, crimes against humanity. Founded on the basis of the Rome Statute, which was adopted in 1998, the International Criminal Court began operating in 2002. Despite the short duration of its activities, it has already shown its effectiveness in several cases. The activities of the International Criminal Court are based on the principles of criminal law inherent in most national legal systems. The article is devoted to the emergence and development of the idea of creating an international criminal court as a body of international criminal justice, operating on a permanent basis. The author highlights the main historical preconditions and political and legal foundations of the International Criminal Court. The main normative legal acts that established responsibility for committing serious and especially serious crimes of a large-scale nature, as well as documents that established the criminal prosecution procedure for such acts are considered and analyzed. At the same time, the author points out the imperfection of temporary international and mixed judicial institutions that existed before the idea of creating a permanent body of criminal justice at the international level. Despite the centuries-old history of war crimes and crimes against humanity, as well as the existence of institutions for the punishment of these crimes, for the first time the idea of creating an international judicial body with jurisdiction to include cases of crimes against war against humanity. The author also cites and analyzes doctrinal approaches to the origin of the idea of creating an International Criminal Court, because scientists of the first half of XX century. Various ideas and concepts were put forward for the establishment of a permanent body of international criminal justice, the competence of which would include the consideration of genocide and other inhumane acts.

Keywords: International Criminal Court, international criminal jurisdiction, international crime, war crimes, crimes against humanity, international treaty. 
Постановка проблеми. Стае дедалі 1 очевидно, що внутрішньо-державні судові системи не завжди здатні адекватно реагувати на злочини, що несуть реальну небезпеку людській цивілізації. Коли національна система функціонуе неефективно і не здатна належним чином уживати заходів у відповідь на злодіяння, вчинені в межах іiі юрисдикції, міжнародне співтовариство не може байдуже дивитися на систематичні i широкомасштабні порушення прав людини. Дослідження основних історичних передумов та політико-правових засад створення Міжнародного кримінального суду допоможе вдосконалити механізм міжнародної кримінальної відповідальності за скоення военних злочинів та злочинів проти людства.

Аналіз останніх досліджень і публікацій. На доктринальному рівні українськими вченими, які зробили значний внесок у дослідження виникнення та розвитку Міжнародного кримінального суду є Базов В.П., Буроменский М.В., Важна К.А., Ведерникова О.Н., Гороховська О.В., Колесніков А.В., Подшибякин А.С., Сироїд Т.Л., Щур Б.В. та інші.

Виділення не вирішених раніше частин загальної проблеми. Наразі вчені так і не дійшли остаточного висновку про час та момент створення Міжнародного кримінального суду. Не існуе також единої сталої переодизації розвитку Міжнародного кримінального суду.

Метою даної наукової статті е дослідження виникнення та розвитку ідеї створення Міжнародного кримінального суду як органу міжнародної кримінальної юстиції, що діятиме на постійній основі.

Виклад основного матеріалу. Починаючи ще 3 часів середньовіччя національні суди держав переможців мали право розглядати та засуджувати воєнні злочини заподіяні сторонами, що зазнавали поразки у воєнному конфлікті. Визнання дії, такою, що е злочинною, залишалась на розсуд переможця.

Першим трунтовним зведенням цих злочинів став Кодекс Лібера (Leiber Code), прийнятий президентом Лінкольном у 1863 році. Кодекс Лібера як перша спроба кодифікації законів і звичаїв війни справив великий вплив на наступні спроби кодифікації, що робили різні конференції й міжнародні установи, оскільки він був основою для їх діяльності. Цей документ мав національний характер, проте здійснив свій вплив на формування міжнародного гуманітарного права, так само, як і фундаментальна кодифікація сучасного міжнародного права «Das moderne Volkerrecht», опублікована в 1868 р. Жаном Гаспаром Блюнчлі, видатним швейцарським юристом, який викладав у Гейдельберге. Ці два документи зумовили вимогу про створення проекту правил про поводження з військовополоненими [1, с. 116].

Далі з'явилася низка міжнародних договорів, зокрема, IV Гаазька конвенція 1907 року і їі статути, чотири Женевські конвенції 1949 року i їх Протоколи 1977 року.

Вперше ідея створення міжнародного судового органу, до юрисдикції якого б входив розгляд справ про військові злочини, з'явилась у післявоєнні роки Першої світової війни.
Так, у 1919 році на Паризькій конференції було прийнято рішення про організацію Постійної палати міжнародного правосуддя (арбітражний суд).

До складу цього суду повинен був обиратись один представник від кожної держави-учасниці.

Передбачалось, що Постійна палата міжнародного правосуддя розробить власну судову процедуру і буде розглядати справи про злочини проти публічного міжнародного порядку і міжнародного права. Пропозиція про створення цієї інституції була прийнята Радою Ліги Націй для обговорення [2, с. 106].

У тому ж 1919 році на Версальській мирній конференції було висвітлено питання засудження кайзера Вільгельма за розв'язання війни Німеччиною. Результатом стало створена комісія, яка склала список з 895 передбачуваних військових злочинців, діяння яких могли бути розглянуті цим судом. Комісія запропонувала віддати під суд і керівників Туреччини, яка перебувала під час війни в союзі з Німеччиною, «за злочини проти законів людства» в зв'язку 3 геноцидом вірмен в 1915 р, що відбувалися на тлі військових дій [3, с. 2].

У вересні 1928 року Міжнародна Асоціація кримінального права подала до Ліги Націй проект власного статуту міжнародного кримінального суду. Згідно з цим статутом до компетенції такого суду входило "обговорення скарг по обвинуваченню держав у «несправедливій агресії» або інших порушень міжнародного права, а також розгляд справ про злочини окремих осіб, що обвинувачувались в агреciї чи в інших злочинах які $б$ трактувались, як міжнародні, оскільки вони містять загрозу мирному співіснуванню держав». Цей проект також не був прийнятий Лігою Націй $[4$, с. 58].

Науковці виділяють також й ще один період становлення міжнародного кримінального правосуддя у міжвоєнний період. Так, вбивство югославського короля Олександра та французького міністра закордонних справ Барту у 1934 році змусило Лігу Націй повернутись до питання міжнародного кримінального суду. Радою цієї організації був створений комітет, що складався з представників одинадцяти держав, для розробки міжнародної конвенції про боротьбу з тероризмом. Комітет, окрім запропонованої конвенції, розробив і конвенцію про міжнародний кримінальний суд.

Обидва проекти довгий час розглядались в багатьох комітетах, поки, нарешті, в листопаді 1937 року на конференції дипломатичних представників у Женеві не приступили до їх підписання. I якщо першу конвенцію «Про попередження тероризму» підписало 24 держави (в тому числі й СРСР), то конвенцію «Про Міжнародний кримінальний суд» - всього 13. Радянський Союз цю конвенцію не підписував [5, с. 13].

Таким чином, до моменту початку Другої світової війни міжнародне право мало у своєму розпорядженні кодекс поведінки у збройних конфліктах, але загальної процедури притягнення до відповідальності не існувало, хоча і робилися певні зусилля на міжнародному рівні: від включення окремих статей у міжнародний договір до укладення спеціальних угод. До того 
ж питання створення Міжнародного кримінального суду детально обговорювалося в Лізі Націй в 1920 і 1935-1937 роках.

Поняття «злочин проти людства" було до цього використано лише один раз у Декларації урядів Великобританії, Росії та Франції, які засудили, згаданий вище, геноцид вірмен у Туреччині у 1915 р., але найбільші зміни, що стосуються цього поняття, відбулися після Другої світової війни.

Всі ці задуми кілька років обговорювались на міжнародних юридичних конференціях, було розроблено чимало проектів, але Міжнародний кримінальний суд так і не було створено.

I хоча через недосконалість норм, які передбачали створення такого суду, а також за відсутності відповідної нормативної бази, яка б регулювала порядок його утворення та діяльності, процедура ведення судового процесу міжнародного кримінального суду так i не була утворена, все ж Версальський мирний договір 1919 року можна вважати своєрідним прецедентом для міжнародного кримінального правосуддя.

Кримінальна юрисдикція держави поширюється в межах всієї їі території. Під неї підпадають усі громадяни цієї держави, а також і громадяни інших держав, що скоїли злочин на їі території. Правовий зв'язок держави з їі громадянином передбачає наявність у них певного взаємопов'язаного комплексу прав і обов'язків.

Тому вчинення громадянином діянь, які держава визнає злочинними, автоматично дає їй право розпочати судове переслідування такої особи. Правовими підставами для такого переслідування $є$ наявність кримінального законодавства, що прямо передбачає, які протиправні діяння $є$ злочинними i яка відповідальність передбачена за їх скоєння $[6$, c. 122$]$.

Німеччина була безсилою, щоб покарати свого колишнього Кайзера за розв'язання Першої світової війни та за їі численні жертви саме через відсутність правових підстав для цього. Внутрішньодержавне кримінальне законодавство не могло передбачати відповідальності за розв'язання агресивної війни та пов'язані 3 цим злочинні діяння, так як злочином може визнаватись лише таке діяння, що посягає на суспільно-політичний лад держави, її економічну систему, права та свободи їі громадян. Держава здійснюе кримінально-правову охорону лише в межах своєї території [7, с. 13].

Поширення дії кримінального закону в просторі за межі суверенної території одніеї держави фрактично означало б порушення суверенітету іншої держави. Більш того, діяння екс-Кайзера не могли бути передбачені як злочинні внаслідок специфічного об'єкту їх посягання, який не охоплювався внутрішньодержавним кримінальним законом.

Отже, можна зробити висновок про необхідність наддержавного регулювання цієї проблеми i про правомірність застосування кримінального правосуддя щодо суб'єктів міжнародних злочинів - фрізичних осіб, винних у їх вчиненні.
Таким чином, Версальський мирний договір вперше в історії міжнародного права фрактично передбачив можливість вилучення фрізичної особи - громадянина 3-під юрисдикції певної держави незалежно від їі волі.

Відповідно до рішення Берлінської (Потсдамської) конференції глави союзних держав (СРСР, США і Великобританії) прийняли рішення про покарання військових злочинців Другої світової війни 1939-1945 рр [8, с. 138].

У Лондоні між урядами СРСР, США, Великобританії і Франції 8 серпня 1945 року було укладено угоду про створення Міжнародного військового трибуналу для переслідування i покарання головних військових злочинців європейських країн. Невід'ємною складовою цієї угоди став Статут Міжнародного військового трибуналу, в якому визначалися його організаційну будову, ффункції і юрисдикція [9]. Засідання Міжнародного військового трибуналу проходили в Нюрнберзі (Німеччина) з 20 вересня 1945 по 1 жовтня 1946 р. Нюрнберзький військовий трибунал став судом народів над військовими злочинцями, які перебували при владі в нацистській Німеччині протягом 1933-1945 pp.

Відповідно до Статуту Міжнародного військового трибуналу його вирок дає чітку правову кваліфікацію тяжким міжнародним злочинам, злочинам проти миру, військових злочинів, злочинів проти людства.

Документи Нюрнберзького процесу також були покладені в основу цілого ряду міжнародноправових актів з питань недопущення геноциду, расизму та расової дискримінації.

Міжнародним кримінальним судом став i Токійський військовий трибунал. Також відповідно до рішень Берлінської (Потсдамської) конференції 1945 р. угодою між урядами США, CРСР, Великобританії, Китаю, Франції, Австралії, Канади, Нової Зеландії, Нідерландів, Індії і Філіппін з 19 січня 1946 р по 12 листопада 1946 р. був створений Міжнародний військовий трибунал для Далекого Сходу.

33 травня 1946 р по 12 листопада 1948 року в столиці Японії - місті Токіо проходив судовий процес, за ведення Японією протягом 1928-1945 pр. агресивних воєн проти Китаю, СРСР, США і інших країн, вчинення військових злочинів і злочинів проти людства. До кримінальної відповідальності було притягнуто 28 високопоставлених чиновників.

Як Нюрнберзький, так і Токійський, ці суди були виключно міжнародними військовими трибуналами. Їх створення і діяльність розглядалася в форматі затвердження післявоєнного міжнародного правопорядку, нового світового перерозподілу окремих територій і «зон впливу». I тому перед цими судами на лаві підсудних з'являлись тільки військові злочинці переможених країн [10, с. 49].

У період проведення Нюрнберзького процесу i надалі чимало юристів вважали, що концепція злочинної організації, прийнята Трибуналом, має спеціальний характер і не виключає можливості визнання злочинною державу в цілому. Відразу ж після закінчення Нюрнберзького процесу фрранцузький член 
Трибуналу Г. Доннедьє де Вабр писав: «Кримінальна відповідальність держави як юридичної особи не виключається Нюрнберзьким вироком» [11, c. 152].

Ідея особливого режиму міжнародної відповідальності держави за скоєння міжнародних злочинів та створення міжнародного

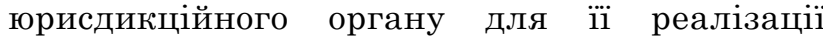
обговорювалася при підготовці проекту Конвенції про попередження i покарання за злочин геноциду 1948 р., під час роботи Комісії міжнародного права над проектом Кодексу злочинів проти миру i безпеки людства [12, с. 487].

Хоча кримінальна відповідальність держави так і не була встановлена при здійсненні кодифікаційної роботи у даній сфрері, питання про міжнародну кримінальну правосуб'єктність держави залишається відкритим. У проект Кодексу включена спеціальна ст. 4 «Відповідальність держав», яка встановлює, що «відповідальність окремих осіб за злочини проти миру і безпеки людства, передбачена в цьому Кодексі, жодним чином не впливає на відповідальність держав за міжнародним правом» [13, c. 114].

У тому ж 1948 року в Генеральній Асамблеї ООН на порядок денний було поставлено питання про можливість створення Міжнародного кримінального суду.

Після ретельного вивчення та обговорення цього питання Комісія міжнародного права у 1950 рощі надала на розгляд Генеральної Асамблеї ООН розгорнуту доповідь, в якому створення такої судової інстанції визнавалося можливим і бажаним.

На початку 50-х pp. XX ст. з'явився перший проект Статуту Міжнародного кримінального суду, але робота над ним не була завершена, оскільки реалізація ідеї юристів залежала від керівників держав і частини політиків, які не хотіли допустити навіть теоретичної можливості постати перед таким міжнародним судом.

31950 р. по 1990 р. робота була паралізована через "холодну війну». За підсумками конфлікту в колишній Югославії в 1993 році Рада Безпеки $\mathrm{OOH}$ заснувала спеціальний міжнародний трибунал для притягнення до відповідальності фізичних осіб, винних у скоєнні військових злочинів, злочинів проти людства i геноциді, а також для припинення вчинення аналогічних злочинів в майбутньому. Це додало певний імпульс зусиллям Комісії міжнародного права, і в 1994 р. Генеральної Асамблеї ООН був представлений проект статуту майбутнього міжнародного кримінального суду.

Створений Генеральною Асамблеєю Підготовчий комітет у 1998 році представив зведений текст документа для розгляду спеціальної дипломатичної конференцією.

Так, у 1998 р. в Римі під егідою ООН пройшла Дипломатична конференція повноважних представників держав - членів ООН щодо створення Міжнародного Кримінального Суду, яка завершилася ухваленням Статуту Міжнародного Кримінального Суду.

Конференція відбулася 15 червня - 17 липня 1998 р. На ній були присутні представники
160 держав, 33 міжнародних міжурядових організацій та 236 неурядових організацій [14, с. 9].

У серпні 2002 р. перша сесія Асамблеї держав-учасниць Статуту прийняла два основних юридичних документа Суду: Правила процедури і доказування і Елементи злочинів.

У лютому 2003 р. були обрані перші 18 суддів, а в квітні 2003 був обраний Прокурор (Луїс Морено-Окампо, Аргентина). Місцем розташування Міжнародного кримінального суду $є$ м. Гаага (Нідерланди).

Науковці по різному ставляться до часу виникнення міжнародного кримінального правосуддя. Так, Крістофер Кейтл Холл - юридичний радник Емнесті Інтернешнл у Міжнародногму секретаріаті цієї організації в Лондоні відзначає, що в історії до XX століття майже всі судові процеси щодо порушення законів війни проводились спеціально створюваними одною із сторін (державою-переможницею, як правило) для таких випадків трибуналами, а не звичайними судами чи міжнародним кримінальним судом. Першим спеціально створеним міжнародним кримінальним судом, на думку науковця, можна вважати збори суддів із міст Ельзаса, Австрії, Німеччини та Швейцарії, засновані 1474 року для судового процесу над де Хагенбахом за злочини проти «законів Господа і людини», вчинені ним під час окупації міста Брайзаха.

До речі, вже тоді, як і під час Нюрнберського Трибуналу, так i після нього, покарання обвинувачених пов'язувалось із вирішенням питання виконання наказів командирів. Проте, як відзначає Д. Шварценбегер, відтоді людству знадобилось понад чотири століття, щоб серйозно замислитись над ідеєю формування міжнародної кримінальної юстиції.

На противагу вказаним науковцям радянські вчені М.Ю. Рагінський та С.Я. Розенбліт вважали, що до Першої світової війни не було жодної спроби створення міжнародного кримінального суду над винуватцями агресивних війн.

Можна погодитись і з Ш. Бассіоні, який відзначає, що традищійна система попередження порушеньправавійнибулавнутрішньодержавною, a не міжнародною. Порушення, що вчинялись під час війни, залишались безкарними, оскільки не було визнано того фракту, що держави несуть відповідальність за військові злочини чи інші порушення міжнародного права, так само як й індивіди в окремих випадках відповідають за міжнародним правом. Єдине, що стримувало воюючі держави від порушення правил і звичаїв війни, була їх добра воля.

Висновки. Отже, стурбованість світового співтовариства кількістю жертв, а також ступенем і обсягом загроз, яка сколихнули світ на початку XX ст. зумовили необхідність створення більш ефективного інструментарію, здатного забезпечити такий світовий порядок, в якому держави будуть поважати норми і договори, добровільно підписані самими ж цими державами. Міжнародний кримінальний суд покликаний певною мірою виконати цю місію, і з цієї точки зору його створення i функціонування являе важливу віху в історії міжнародного права, так і всього розвитку людської цивілізації. 


\section{Список літератури:}

1. Гороховська О.В. Кодекс Ліберала та його значення для розвитку й кодифікації Міжнародного гуманітарного права. Держава та регіони. Сер. Право. 2014. № 2. С. 114-118.

2. Щур Б.В. Діяльність Міжнародного кримінального суду: історія і перспективи. Украӥнський часопис міжнародного права. 2016. № 5. С. 106-109.

3. Подшибякин А.С. Міжнародний кримінальний суд і проблеми національного законодавства. Міжнародне кримінальне право і міжнародна юстищія. 2008. № 1. С. 2-5.

4. Колесніков А.В. Що таке Міжнародний кримінальний суд. Влада. 2008. № 28. С. 56-62.

5. Ведерникова О.Н. До питання про ратифікацію Римського Статуту Міжнародного кримінального суду. Кримінальне судочинство. 2015. № 4. С. 13-16.

6. Марочкин С.Ю. Проблема әффективности норм международного права. Изд-во Иркутского университета. 1988. № 3. C. $122-124$.

7. Мацько А. Международный уголовный суд. История создания и серера деятельности. Персонал. 2012 . № 8. C. $12-16$.

8. Сироїд Т.Л. Жертви злочинів під захистом міжнародного співтовариства. Вісник Запорізького юридичного iнституmy. 2003. № 2. C. 138-141.

9. Статут Міжнародного військового трибуналу для суду та покарання головних військових злочинців европейських країн осі від 08.08.1945 № 998_201. URL: http://zakon.rada.gov.ua/laws/show/998_201

10. Буроменский М.В. Значение международной уголовно-правовой юрисдикции в борьбе с организованной преступностью. Збірник наукових пращь Харківського Центру з вивчення організованої злочинності. Сер. Право. 2001. № 2. С. 48-67.

11. Лукашук I.I., Наумов А.В. Міжнародне кримінальне право : навч. посібник. Київ, 371 с.

12. Важна К.А. Концепція кримінальної відповідальності держави у доктрині міжнародного права. Держава $i$ право. 2016. № 56. С. 485-491.

13. Гетьман-Павлова И.В. Международное право : учебник. Москва: Юристъ, 2006. 262 с.

14. Базов В.П. Кримінальна відповідальність за серйозні порушення міжнародного гуманітарного права : навч. посібник. Київ : Істина, 2003. 135 с.

\section{References:}

1. Horokhovska O.V. (2014) Kodeks Liberala ta yoho znachennia dlia rozvytku y kodyfikatsii Mizhnarodnoho humanitarnoho prava [The Liberal Code and its significance for the development and codification of international humanitarian law]. Derzhava ta rehiony. Ser. Pravo, no. 2, pp. 114-118.

2. Shchur B.V. (2016) Diialnist Mizhnarodnoho kryminalnoho sudu: istoriia i perspektyvy [Activities of the International Criminal Court: history and prospects]. Ukrainskyi chasopys mizhnarodnoho prava, no. 5, pp. 106-109.

3. Podshybiakyn A.S. (2008) Mizhnarodnyi kryminalnyi sud i problemy natsionalnoho zakonodavstva [International Criminal Court and problems of national legislation]. Mizhnarodne kryminalne pravo i mizhnarodna yustytsiia, no. 1 , pp. $2-5$.

4. Kolesnikov A.V. (2008) Shcho take Mizhnarodnyi kryminalnyi sud [What is the International Criminal Court]. Vlada, no. 28, pp. 56-62.

5. Vedernykova O.N. (2015) Do pytannia pro ratyfikatsiiu Rymskoho Statutu Mizhnarodnoho kryminalnoho sudu [On the question of ratification of the Rome Statute of the International Criminal Court]. Kryminalne sudochynstvo, no. 4, pp. 13-16.

6. Marochkyn S.Iu. (1988) Problema effektyvnosty norm mezhdunarodnoho prava [The problem of the effectiveness of international law]. Yzd-vo Yrkutskoho unyversyteta, no. 3, pp. 122-124.

7. Matsko A. (2012) Mezhdunarodnyi uholovnyi sud. Ystoryia sozdanyia y sfera deiatelnosty [International criminal court. History of creation and field of activity]. Personal, no. 8, pp. 12-16.

8. Syroid T.L. (2003) Zhertvy zlochyniv pid zakhystom mizhnarodnoho spivtovarystva [Victims of crimes under the protection of the international community. Bulletin of the Zaporizhia Law Institute]. Visnyk Zaporizkoho yurydychnoho instytutu, no. 2, pp. 138-141.

9. Statut Mizhnarodnoho viiskovoho trybunalu dlia sudu ta pokarannia holovnykh viiskovykh zlochyntsiv yevropeiskykh krain osi vid 08.08.1945 № 998_201. [Statute of the International Military Tribunal for the Trial and Punishment of Major War Criminals of the European Axis Countries of 08.08.1945 № 998_201]. URL: http://zakon.rada.gov.ua/laws/show/998_201

10. Buromenskyi M.V. (2001) Znachenye mezhdunarodnoi uholovno-pravovoi yurysdyktsyy v borbe s orhanyzovannoi prestupnostiu [The importance of international criminal law jurisdiction in the fight against organized crime]. Zbirnyk naukovykh prats Kharkivskoho Tsentru z vyvchennia orhanizovanoi zlochynnosti. Ser. Pravo, no. 2. pp. 48-67.

11. Lukashuk I.I., Naumov A.V. Mizhnarodne kryminalne pravo: navch. posibnyk [International criminal law: a textbook]. Kyiv, $371 \mathrm{p}$

12. Vazhna K.A. (2016) Kontseptsiia kryminalnoi vidpovidalnosti derzhavy u doktryni mizhnarodnoho prava [The concept of criminal responsibility of the state in the doctrine of international law]. Derzhava $i$ pravo, no. 56, pp. 485-491.

13. Hetman-Pavlova Y.V. (2006) Mezhdunarodnoe pravo: uchebnyk [International law: textbook]. Moscow: Yuryst, 262 p.

14. Bazov V.P. (2003) Kryminalna vidpovidalnist za seriozni porushennia mizhnarodnoho humanitarnoho prava: navch. posibnyk [Criminal liability for serious violations of international humanitarian law: textbook]. Kyiv: Istyna, $135 \mathrm{p}$. 